\title{
Virulence Variability of Puccinia coronata f. sp. avenae Isolates Collected in Three Counties from Rio Grande do Sul State, Brazil
}

\author{
E. A. Vieira, Ph.D., Embrapa Cerrados, C.P. 8223, 73310-970, Planaltina, DF, Brazil; F. I. F. Carvalho, Ph.D., Uni- \\ versidade Federal de Pelotas, C.P. 354, 96010-900, Pelotas, RS, Brazil; M. S. Chaves, Ph.D., Embrapa Trigo, C.P. \\ 451, 99001-970, Passo Fundo, RS, Brazil; A. Costa de Oliveira, Ph.D., Universidade Federal de Pelotas, Brazil; G. \\ Benin, Ph.D., Universidade Tecnológica Federal do Paraná, Rodovia PR 469, km 01, 85501-970, Pato Branco, PR, \\ Brazil; and I. Hartwig, M.Sc., J. A. G. Silva, Ph.D., I. Bertan, M.Sc., A. F. Martins, B.Sc., and L. F. Martins, \\ M.Sc., Universidade Federal de Pelotas, Brazil
}

\begin{abstract}
Vieira, E. A., Carvalho, F. I. F., Chaves, M. S., Costa de Oliveira, A., Benin, G., Hartwig, I., Silva, J. A. G., Bertan, I., Martins, A. F., and Martins, L. F. 2007. Virulence variability of Puccinia coronata f. sp. avenae isolates collected in three counties from Rio Grande do Sul State, Brazil. Plant Dis. 91:66-70.

Using isolates collected in three counties of Rio Grande do Sul State, Brazil, the goals of this work were to determine (i) the pattern of virulence or avirulence of the isolates to $25 P c$ resistance genes, (ii) the similarity in virulence among Puccinia coronata f. sp. avenae isolates considering their pattern of virulence or avirulence, (iii) the race code for each isolate by the North American system of nomenclature, and (iv) the supplemental $P C$ genes potentially useful as local differentials for $P$. coronata f. sp. avenae races. The results indicate that the southern Brazilian rust isolates presented a high level of virulence, because $66 \%$ of inoculations manifested the high infection type. Only the $P c 68$ gene was effective against all tested isolates. In general, each isolate presented a different pattern of virulence or avirulence, which indicates the high variability for virulence that the fungus presents at the sampled sites. However, the North American system of nomenclature was not completely sufficient in distinguishing southern Brazilian races. Thus, the genes $P c$ 36, Pc 53, Pc 55, and $P c 63$ represent a possible gene combination to be incorporated into the North American system of nomenclature.
\end{abstract}

Additional keywords: Avena sativa L., genetic resistance

In the southern region of Brazil, hexaploid oat (Avena sativa L.) is one of the most important winter cereals and is used for grain production (food and feed purposes) in rotation with wheat, as well as a cold-season pasture (1,5). Brazilian oat breeding programs started releasing cultivars in the 1980s, breaking a tradition in which most of oat cultivars recommended for commercial use in Brazil were bred in Uruguay and Argentina. Ever since, oat breeding in Brazil has achieved excellent results for high yield, seed size and weight, number of grains per panicle, plant stature, aluminum tolerance, and cold tolerance (1).

Despite the progress attained for adaptative characters and the industrial quality (milling yield) of white oat crops, few gains have been obtained relative to resistance to crown rust (caused by Puccinia coronata f. sp. avenae) in Brazil, and this is the most important disease affecting oat production (21). The pathogen limits yield

Corresponding author: E. A. Vieira

E-mail: vieiraea@cpac.embrapa.br

Accepted for publication 25 August 2006.

DOI: 10.1094/PD-91-0066

(C) 2007 The American Phytopathological Society potential and grain quality in susceptible genotypes in Brazil $(2,4,9,19,21)$, as well as worldwide $(11,13)$.

Despite being the most efficient type of disease control, vertical genetic resistance is considered to have low durability, such that genotypes remain resistant for relatively short time periods $(7,15)$. In particular, the resistance determined by one or a few genes can be overcome by new pathogen races that arise by mutation or that migrate from other locations and increase in frequency due to strong selection pressure from the cultivation of uniformly resistant genotypes over large areas (12).

Studies performed in Brazil have indicated the existence of a great number of distinct physiological races of $P$. coronata f. sp. avenae as well as the presence of complex races ("super races") in southern Brazil. In 1997, Martinelli et al. (20) collected 53 fungal samples in Rio Grande do Sul (RS), Santa Catarina, and Paraná States and identified 53 distinct races, each carrying from 10 to 26 virulence genes, with an average of 20 genes per isolate. Cruz et al. (10) evaluated 28 oat differential near-isogenic lines for $P$. coronata $(P c)$ resistance genes in the field and all expressed the disease. Leonard and Martinelli (18) determined the virulence pattern for $27 P c$ genes of 144 southern-Brazilian fungal isolates (collected between 1997 and 1999), 36 Uruguayan isolates (collected in1994 and in 1998), and 17 Russian isolates (collected in 1995). Within the southern Brazilian and the Uruguayan isolates, Leonard and Martinelli (18) determined that $70 \%$ were virulent for 30 to $70 \%$ of the differentials, that there were a large number of fungal races, and that there was no prevailing race. Moreover, Leonard and Martinelli (18) observed that the complexity in virulence of southern Brazilian and Uruguayan isolates was greater than the complexity in virulence of Russian isolates.

Previous works have provided valuable insights regarding the variability and the complexity of southern Brazilian P. coronata f. sp. avenae populations. However, it is essential to continuously survey $P$. coronata $\mathrm{f}$. sp. avenae races occurring in this region in order to understand the diversity, complexity, and evolutionary rate of pathogen populations (arising from new races). Through such surveys, it will be possible to determine prevailing races in major oat cultivation regions, and to detect virulence phenotypes that pose a threat to currently grown oat cultivars. Surveys of virulence phenotypes in cereal rusts can provide information on the effectiveness of currently used resistance genes and the potential effectiveness of genes that have not yet been widely deployed in commonly grown cultivars and to give support to local breeding programs aiming to improve cultivar resistance levels.

Based on the analysis of 46 pathogen isolates collected in three counties of Rio Grande do Sul State, Brazil, the goals of this work were to determine (i) the pattern of virulence or avirulence of the isolates to $25 P c$ resistance genes, (ii) the similarity in virulence among $P$. coronata f. sp. avenae isolates considering their pattern of virulence or avirulence, (iii) the race code for each isolate by the North American system of nomenclature for $P$. coronata f. sp. avenae (Pca code), and (iv) supplemental $P c$ genes potentially useful as local differentials for $P$. coronata f. sp. avenae races.

\section{MATERIALS AND METHODS}

Leaf samples with rust symptoms were collected from the Brazilian Recom- 
mended Oat Cultivars Field Trial (EBCRA), from 22 to 29 September 2003 (soon after plant flowering), in three locations (counties) of RS State: (i) Passo Fundo (PF), located at $28^{\circ} 15^{\prime} 46^{\prime \prime}$ latitude south and $52^{\circ} 24^{\prime} 24^{\prime \prime}$ longitude west at an altitude of $687 \mathrm{~m}$; (ii) Capão do Leão (CL), located at $31^{\circ} 52^{\prime} 00^{\prime \prime}$ latitude south and $52^{\circ} 21^{\prime} 24^{\prime \prime}$ longitude west at an altitude of $13.24 \mathrm{~m}$; and (iii) Eldorado do Sul (EL), situated at $30^{\circ} 05^{\prime} 22^{\prime \prime}$ latitude south and $51^{\circ} 39^{\prime} 08^{\prime \prime}$ longitude west at an altitude of $46 \mathrm{~m}$. Leaf samples were air dried at room temperature for about $48 \mathrm{~h}$ and then stored at $4^{\circ} \mathrm{C}$ at the Wheat Leaf and Stem Rusts Laboratory of Brazilian National Research Center for Wheat (EMBRAPA) at Passo Fundo, RS. Cv. UFRGS 7, which has exhibited high susceptibility to crown rust in Brazil, was used as a susceptible check (SC) for multiplying field isolates. Seedlings of SC with a completely exposed first leaf (7 days after sowing) were sprayed with Tween 20 solution $\left(10 \mu \mathrm{l} 100 \mathrm{ml}^{-1}\right)$; then, each seedling was inoculated with a single collected fungal sample by scratching the spores using a sterilized spatula. After inoculation, each seedling was isolated in a plastic cone to avoid cross contamination between fungal isolates and placed in a dark chamber at $100 \%$ relative humidity and $20^{\circ} \mathrm{C}$ for $18 \mathrm{~h}$. Seedlings were maintained in a greenhouse between 20 and $24^{\circ} \mathrm{C}$ and 60 to $80 \%$ relative humidity.

After 15 days in the greenhouse, a single pustule was selected on each inoculated plant and spores collected from that single pustule were used to inoculate another seedling, repeating the procedures of the original inoculations. After 15 days, the procedures were repeated for each monopustular isolate. The strategy of two consecutive single-pustule isolations was chosen to guarantee the purity of obtained isolates and, therefore, increase the precision of race identification.

After being submitted to two consecutive single-pustule isolations, the spores of each of the 46 isolates were multiplied in five SC seedlings and 15 days later were collected with the help of an air pump and stored in a vacuum in glass tubes at $4^{\circ} \mathrm{C}$. These spores later were resuspended in water at a concentration of $10^{5}$ spores $\mathrm{ml}^{-1}$, then sprayed onto seedlings of $25 P c$ nearisogenic lines at the stage of completely exposed first leaf (7 days after sowing). Before inoculation, seedlings were sprayed with a water-Tween 20 solution $(10 \mu \mathrm{l} 100$ $\mathrm{ml}^{-1}$ ). After inoculation, they were protected by a plastic cone (to avoid crosscontamination among isolates) and placed in a $100 \%$ humidity dark chamber for $18 \mathrm{~h}$ at $20^{\circ} \mathrm{C}$ for spore germination and penetration. Afterward, seedlings were maintained in greenhouse conditions at between 20 and $24^{\circ} \mathrm{C}$ and 60 to $80 \%$ humidity. From the $25 P c$ near-isogenic lines evaluated, 16 were from the North American System of Nomenclature (NASN), proposed by Chong et al. (8) (Pc 40, Pc 45, Pc 46, Pc 50, Pc 38, Pc 39, Pc 48, Pc 68, Pc 51, Pc 52, Pc 58, Pc 59, Pc 54, Pc 56, Pc 62, and $P c$ 64) and 9 were additional $P c$ isogenic lines $(P c$ 14, Pc 35, Pc 36, Pc 53, Pc 55, $P c$ 57, $P c$ 60, $P c$ 61, and $P c$ 63). The crown rust resistance genes evaluated were derived from collections of wild oat $A$. sterilis, except for the $P c 14$ gene, which is from Ascencao, a Brazilian cultivar of $A$. sativa (18).

Fifteen days after inoculation of the near-isogenic lines, reactions were scored according to a scale from 0 to 4 , where $0=$ absent uredia or other macroscopic infection symptoms, $1=$ small uredia sur- rounded by chlorosis or necrosis, $2=$ small to medium size uredia surrounded by chlorosis, $3=$ medium size uredia in a chlorotic area, and $4=$ large uredia without chlorosis or necrosis. Responses 0,1 , and 2 were considered indicative of host resistance (low infection type) and responses 3 and 4 were considered indicative of host susceptibility (high infection type) (22). Each isolate showed a particular combination of high and low infection types (virulence or avirulence) for the $P c$ genes of the differentials and received a letter code according to the NASN for $P$. coronata $\mathrm{f}$. sp. avenae (8). The NASN allows the addition of new subgroups of four $P c$ genes and the addition of new letters to the right of the currently used letters. Thus, the additional $P C$ genes used in these tests were evaluated for their potential as local race differentials.

The virulence or avirulence patterns of isolates for each one of the studied $P c$ genes were transformed to a binary scale where $1=$ high infection type or virulence and $0=$ low infection type or avirulence. The similarity of virulence was estimated for each pair of isolates, through an index of simple coincidence (ISC) according to the equation ISC $=\mathrm{C} / \mathrm{N}$, where $\mathrm{C}$ is the number of differential lines on which a pair of isolates was either virulent or avirulent, and $\mathrm{N}$ is the total number of differential lines used (24). Based on the generated similarity matrix, a dendrogram was constructed using the unweighted pair group method with arithmetic means (25). To verify the adjustment between the similarity matrix and the obtained dendrogram, a cophenetic correlation coefficient $(r)$ was calculated according to Sokal and Rolf (26), with the NTSYS pc 2.1 program (23).

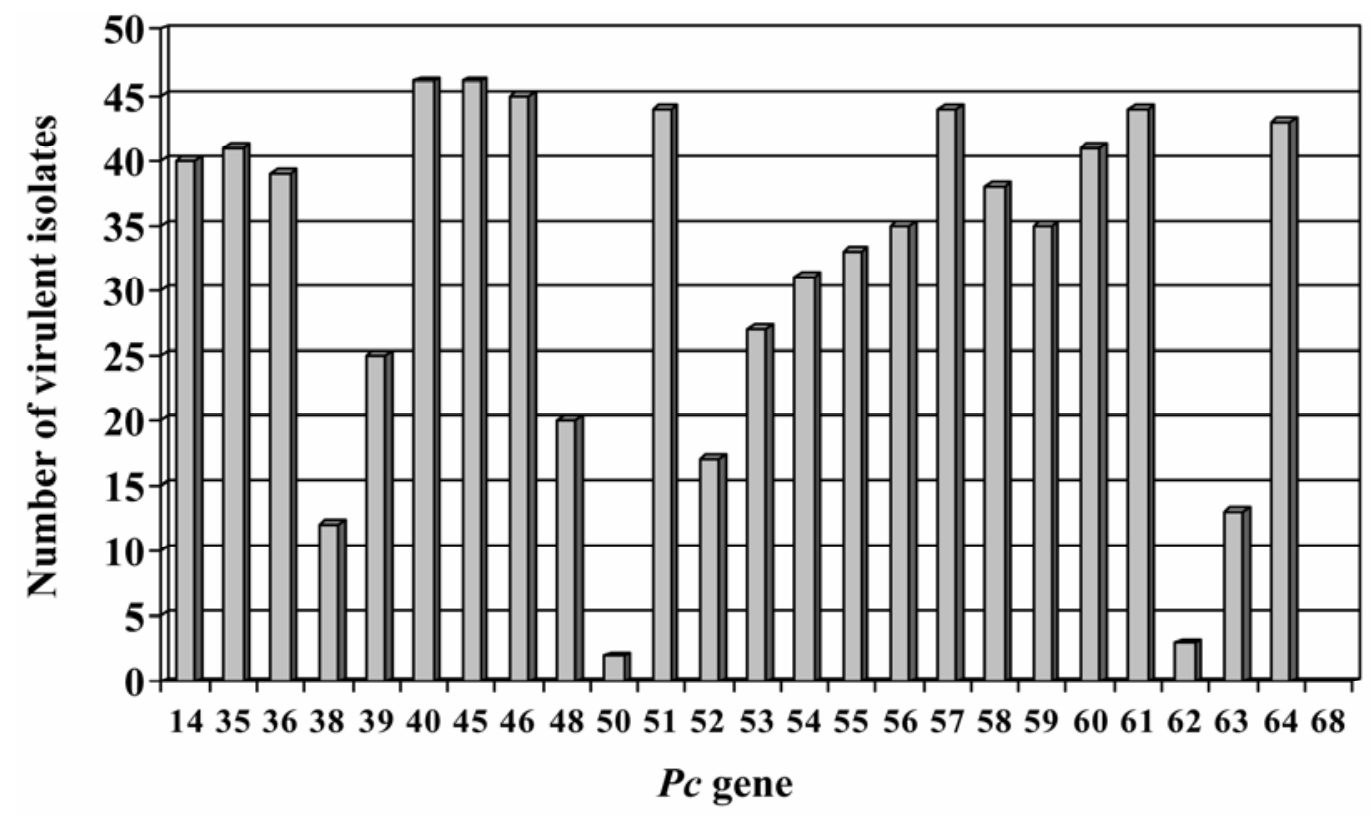

Fig. 1. Number of the 46 isolates of Puccinia coronata f. sp. avenae originated from Capão do Leão (CL), Passo Fundo (PF), and Eldorado do Sul (EL) counties, displaying virulence (high infection type) on each of the 25 Pc genes studied. 


\section{RESULTS}

From all samples collected and purified, 46 isolates of $P$. coronata $f$. sp. avenae were used in this study, with 15 from PF, 15 from EL, and 16 from CL. Inoculation of the 46 isolates on each of the $25 P c$ near-isogenic lines resulted in 1,150 infection sites, of which $764(66 \%)$ showed a and 386 (34\%) showed an avirulence reaction response (low infection type). Seven of the differentials ( $P c 40, P c$ 45, $P c$ 46, $P c$ 51, $P c$ 57, $P c$ 61. and $P c$ 64) were susceptible to more than $90 \%$ of the isolates tested (Fig. 1). Only $P c$ 38, $P c 48, P c 50$, $P c$ 52, $P c$ 62, $P c$ 63, and $P c 68$ were resistant to more than $50 \%$ of the isolates in our tests (Fig. 1). The gene Pc 68 was the most resistant differential because none of our isolates was virulent on it (Fig. 1).

Based only on the $P c$ genes from the NASN for the fungus $P$. coronata $f$. sp. avenae, it was possible to classify the 46 isolates in 30 distinct races (Table 1). The most frequent race was SBPH, which occurred six times (13\%), but was not detected in CL. The second most frequent virulence response (high infection type)

race was SDTH, which occurred four times $(8.7 \%)$ but was not detected in PF. Another two races (SJTR and SJRR) occurred three times $(6.5 \%)$, whereas four races occurred two times $(4.3 \%$; SSSR, SQNM, SDPH, and SGPM). Twenty-two races were detected only once (Table 1 ).

With the goal of quantifying the efficiency of the NASN for identifying races of the fungus $P$. coronata $\mathrm{f}$. sp. avenae in southern Brazil, a comparison was made with the isolate virulence similarity, considering all 25 genes used in the present work. Only the isolates that presented the same virulence and avirulence pattern for all $25 P c$ genes revealed an index of simple coincidence of $100 \%$ (i.e., were completely similar). Of the six isolates classified as race SBPH according to the NASN of fungus $P$. coronata $\mathrm{f}$. sp. avenae, five had a similarity of $100 \%$ when the data from all $25 P c$ genes were used, indicating that such isolates probably represent the same race (Fig. 2). The only isolate that did not present $100 \%$ similarity was EL3, which has one extra virulence gene (Fig. 2). For the second most frequent race,

Table 1. Puccinia coronata f. sp. avenae isolates collected in Capão do Leão (CL), Passo Fundo (PF), and Eldorado do Sul (EL) Counties, nomenclature according to the North American System (NASN) only, nomenclature including a new subset of $P c$ genes $(P c$ 36, $P c 53, P c 55$, and $P c$ 63) as local differentials, and number of virulence (vir) or avirulence (avr) genes for each isolate for the $25 P c$ genes used

\begin{tabular}{|c|c|c|c|}
\hline Isolates & NASN & $\begin{array}{c}\text { NASN plus } P c \\
\text { genes subset }\end{array}$ & $\begin{array}{l}\text { No. of vir/avr } \\
\text { genes }\end{array}$ \\
\hline EL3 & SBPH & SBPHS & $16 / 9$ \\
\hline EL8, PF1, PF6, PF11 and PF12 & SBPH & SBPHQ & $15 / 10$ \\
\hline EL2 & SDTH & SDTHS & $18 / 7$ \\
\hline EL9, EL10 and CL15 & SDTH & SDTHQ & $17 / 8$ \\
\hline EL5, EL13 & SJTR & SJTRN & $19 / 6$ \\
\hline EL11 & SJTR & SJTRS & $20 / 5$ \\
\hline EL15 & SJRR & SJRRS & $19 / 6$ \\
\hline CL13 and CL14 & SJRR & SJRRN & $18 / 7$ \\
\hline CL10 and CL11 & SSSR & SSSRP & $20 / 5$ \\
\hline CL5 and PF5 & SQNM & SQNMP & $16 / 9$ \\
\hline PF10 & SDPH & SDPHS & $17 / 8$ \\
\hline PF14 & SDPH & SDPHG & $13 / 12$ \\
\hline CL1 & SGPM & SGPMJ & $16 / 9$ \\
\hline PF3 & SGPM & SGPMS & $16 / 9$ \\
\hline EL6 & QGTT & QGTTS & $19 / 6$ \\
\hline CL4 & SBNR & SBNRN & $15 / 10$ \\
\hline PF7 & SBPG & SBPGQ & $14 / 11$ \\
\hline PF15 & SBPM & SBPMS & $15 / 10$ \\
\hline EL7 & SBPR & SBPRQ & $16 / 9$ \\
\hline EL1 & SDMH & SDMHS & $15 / 10$ \\
\hline CL2 & SDPR & SDPRG & $15 / 10$ \\
\hline CL16 & SDTG & SDTGQ & $12 / 13$ \\
\hline EL12 & SJSR & SJSRN & $18 / 7$ \\
\hline PF13 & SGFM & SGFMK & $15 / 10$ \\
\hline CL12 & SGLR & SGLRN & $14 / 11$ \\
\hline CL3 & SGNQ & SGNQN & $14 / 11$ \\
\hline EL4 & SGTR & SGTRN & $17 / 8$ \\
\hline PF2 & SLBM & SLBMK & $12 / 13$ \\
\hline CL9 & SLMR & SLMRF & $16 / 9$ \\
\hline CL8 & SQMM & SQMMP & $17 / 8$ \\
\hline PF4 & SQPR & SQPRP & $19 / 6$ \\
\hline PF9 & SQPT & SQPTF & $17 / 8$ \\
\hline PF8 & SSNM & SSNMP & $18 / 7$ \\
\hline EL14 & SSTM & SSTMT & $21 / 4$ \\
\hline CL7 & TGNM & TGNMS & $17 / 8$ \\
\hline CL6 & TQPT & TQPTP & $21 / 4$ \\
\hline Average $^{a}$ & $\ldots$ & $\ldots$ & $17 / 8$ \\
\hline
\end{tabular}

a Average of virulence/avirulence genes.
SDTH, three isolates were identical, but the fourth had an extra virulence gene (Table 1; Fig. 2). Races SJTR and SJRR each had two identical isolates and one distinct isolate when all 25 differentials were considered. Races SSSR and SQNM had two identical isolates each, but races SDPH and SGPM had two distinct isolates each based on all 25 differentials. Considering the three collecting locations, there was no clear pattern of virulence variability distribution (Fig. 2), because the isolates did not cluster according to the collecting location and a high number of overlaps were detected among the isolates from different locations.

The use of all $25 P c$ genes increased the number of isolates with different virulence or avirulence patterns from 30 (NASN only) to 36 (Fig. 2). Among the sampled isolates, those which presented the highest number of virulence genes were CL6 and EL4, with 21 genes, whereas isolates that revealed the lowest number of virulence genes were CL16 and PF2, with 12 virulence genes each. The most frequently collected isolate, SBPH, was observed to have 15 virulence genes and the average number of virulence genes per isolate was 17 genes (Table 1).

\section{DISCUSSION}

The inoculation of the 46 southern Brazilian $P$. coronata f. sp. avenae isolates on the $25 P C$ near-isogenic lines resulted in $66 \%$ virulence response and $34 \%$ avirulence reaction response, which indicates generally high virulence of these isolates. Similar result was reported by Leonard et al. (17) with Israeli P. coronata f. sp. avenae isolates.

The differentials $P c$ 40, $P c$ 45, $P c$ 46, $P c$ 51, $P C$ 57, $P C$ 61, and $P c 64$ were susceptible to more than $90 \%$ of the isolates tested. Leonard and Martinelli (18) found that $P C$ 45, $P c$ 46, Pc 57, $P c$ 60, and $P c 61$ were susceptible to more than $90 \%$ of the isolates that they collected in southern Brazil in 1997, but these differentials were susceptible to somewhat lower proportions (18 to $87 \%$ ) of the isolates collected in 1998 and 1999. Only Pc 38, Pc 48, Pc 50, $P c$ 52, $P c$ 62, Pc 63, and $P c 68$ were resistant to more than $50 \%$ of the isolates in the present work, and this is consistent with the low frequencies of virulence to these differentials among the isolates Leonard and Martinelli (18) evaluated from 1997 to 1999.

None of our isolates was virulent on $P c$ 68, showing that the $P c 68$ gene was the most resistant differential, which also is similar to observations by Leonard and Martinelli (18), who found (in 1997 to 1999) only 1 of 144 isolates from southern Brazil that was virulent on $P c$ 68. This gene is widely recognized as one of the most effective genes against this fungus $(6,14)$. Despite the fact that the present work did not detect any $P c$ 68-virulent 
isolate, this result is not conclusive evidence of the nonexistence of virulent isolates to this gene in southern Brazil, because the studied isolates were collected in the EBCRA, where none of the cultivars present this gene. In case one isolate would contain the $P c 68$ avirulence gene, this isolate would have a reduced fitness due to an unnecessary gene for virulence, possibly resulting in a competitive disadvantage against other non- $P c$ 68-containing isolates. Thus, an isolate containing this unnecessary gene will tend to occur in lower frequency. Because the number of isolates herein studied was relatively small, it is possible that, because of a sampling error, this particular $P c 68$ isolate has not been collected. Nevertheless, $P c 68$ is a potential source of resistance to the pathogen, but this only can be proven after its use in large areas for long periods of time.

Crown rust isolates collected on the California Islands in the United States were not virulent to $P c 38, P c 39, P c 50$, $P c$ 52, $P c$ 56, $P c$ 62, and $P c 68$ and were not avirulent to $P c 14, P c 45, P c 46$, and $P c 54$ (14). These results partially agree with the results herein described because, among the southern Brazilian isolates (i) virulence to $P c 68$ was not detected, (ii) the $P c$ genes $P c$ 38, $P c$ 50, and $P c 62$ were effective against a large number of isolates, (iii) the gene $P c 45$ was not effective against any isolate, (iv) the $P c 46$ gene was effective against only one isolate, and (v) the $P c 54$ gene was effective against only
$33 \%$ of the isolates. However, the results disagree regarding the genes $P c 39, P c 52$, and $P c$ 56, which presented virulent isolates in the present work. Leonard (16) also found high frequencies of virulence to $P c$ 14, Pc 45, Pc 46, and Pc 54 in isolates collected in California from 1990 to 2000, and a few isolates virulent to $P c 68$ in the same period. Leonard (16) indicated that the virulence to $P C 45, P C 46$, and $P C 54$ occurred at high frequency in southern Europe but not in northern Europe or in the United States, except for California. It is also interesting that van Niekerk et al. (27) found that virulence to $P c 45, P c 46$, and $P c 54$ occurred at very high frequency in South Africa, and that Leonard and Martinelli (18) detected relatively high frequencies of virulence to $P c 45, P c 46$, and $P c$ 54 in Brazilian and Uruguayan isolates. The reason for this apparent association of greater virulence in warmer climates is yet not clear.

The use of all $25 P C$ genes (16 from NASN and 9 others) increased the number of isolates with different virulence or avirulence patterns from 30 (NASN only) to 36 . Such results indicate the presence of high variability in the population and the need for including new $P c$ genes in the NASN, for a better discrimination of Brazilian crown rust isolates. Therefore, we propose the inclusion of a new subgroup of four $P c$ genes $(P c$ 36, $P c$ 53, $P c$ 55, and $P c$ 63 , in that order) to the NASN for the fungus $P$. coronata f. sp. avenae. The $P c 53$,
Pc 55, and Pc 63 genes candidates are to be added to the NASN as a new subgroup, because they presented a relative balance between the number of virulent and avirulent isolates. The $P c 36$ gene, which presented the lowest percentage of virulent isolates among the remainder genes, also is proposed as part of this addition. Chong et al. (8) chose not to include the $P c 55$ and $P c 63$ genes in the NASN differentials, because these genes presented identical reactions to those of the $P c 39$ and $P c 38$ genes, respectively, when tested against Canadian isolates of the fungus. Nevertheless, in the present work, we suggest the inclusion of these genes in the nomenclature system, because these genes presented different reactions toward the Brazilan isolates herein evaluated, which also is in agreement with results reported by Martinelli et al. (20), Cruz et al. (10), and Leonard and Martinelli (18). The inclusion of four additional herein-proposed genes in the NASN differential set was effective, because it divided the 46 isolates into 36 distinct races, as well as the use of all 25 $P c$ genes here evaluated.

Both the NASN and our proposed set of 20 differentials indicated the presence of high virulence variability among the southern Brazilian isolates and the nonexistence of a predominant race. These results are in agreement with those of Martinelli et al. (20), who detected 53 distinct races among 53 southern Brazilian isolates. Nevertheless, the results reported by

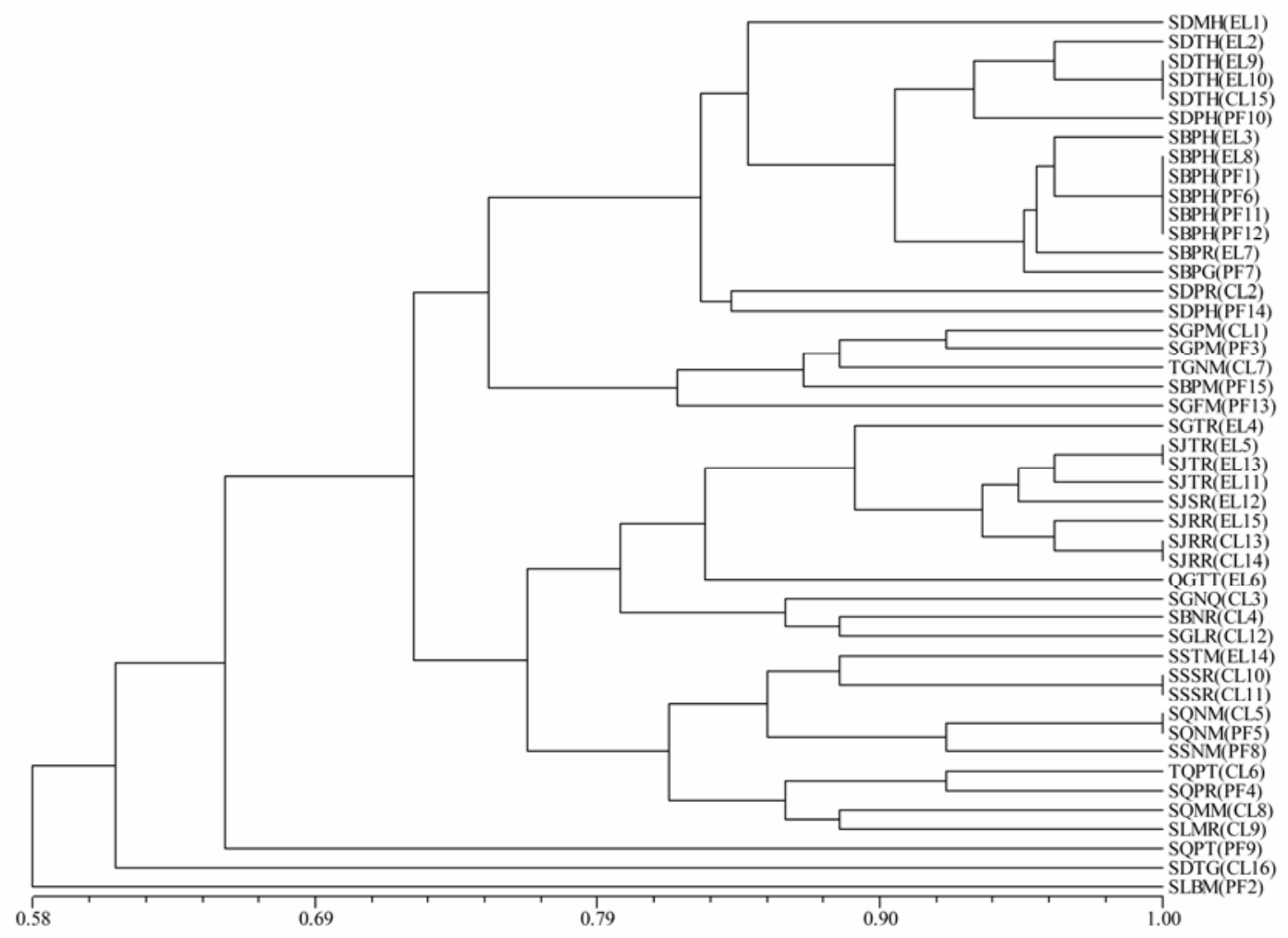

Fig. 2. Dendrogram of 46 Puccinia coronata f. sp. avenae isolates, collected in three Rio Grande do Sul counties, Passo Fundo (PF), Capão do Leão (CL), and Eldorado do Sul (EL), with their respective nomenclatures according to the North American System for Nomenclature (8). The dendrogram was obtained through the unweighted pair group method with arithmetic means clustering method from the similarity index of simple coincidence, based on the patterns of virulence and avirulence of the 46 isolates to the $25 P c$ genes employed in this study. The value of the cophenetic correlation coefficient is 0.82 . 
van Niekerk et al. (27) show less diversity in $P$. coronata in South Africa than in Brazil. Van Niekerk et al. (27) evaluated isolates collected from eight locations over 2 years and found only five races (SBLL, SGLL, PBBB, SDQL, and JBBM) based on the NASN differentials. Among these races, only SBLL occurred at high frequency. We did not find any of the South African races in Brazil.

The isolates CL6 and EL4 presented the highest number of virulence genes (21 genes), whereas the isolates CL16 and PF2 presented the lowest (12 genes). SBPH was the most frequent isolate, presenting 15 virulence genes. With 17 genes as the average number of virulence genes per isolate, results indicate high pathogen race variability and a high number of super races. Thus, in Brazil, these two phenomena could explain the great difficulties faced by Brazilian oat breeders when selecting for crown rust resistance. The occurrence of super races in such high frequency occurs neither in the pathogen's center of origin in Israel (17) nor in the California Islands, where the isolates present six virulence genes on average (14).

Among the possible causes for such high variability in populations of the fungus causing crown rust, the most accepted are (i) recombination of virulence genes via sexual crossings, (ii) asexual recombination via anastomosis (hyphal fusion), and (iii) mutation stockpiling (7). In Brazil, there are no reports of a sexual cycle for this fungus, making asexual recombination or mutation stockpiling the major contributory factors of such high variability. Such evolutionary mechanisms probably are potentialized in Brazil due to the fact that pathogens are broadly spread by wind (3), and that the oat is cultivated year-round in the southernmost countries of South America. It is expected that asexual recombination and mutations do occur year round and are widespread in this region. Another possible explanation is the fact that the isolates were collected in the EBCRA, where there is a high concentration of elite genotypes presenting a large number of resistance genes. Such a collection would generate strong selection pressure, leading to the establishment of a high number of virulence genes.

Apparently, there is no clear pattern of virulence variability distribution among the three collecting locations herein analyzed, because the isolates did not cluster according to the collecting location. There are two possible explanations for the absence of local clustering tendency: (i) the ease of dispersal allows all isolates to be uniformly distributed throughout different locations or (ii) the isolates were collected on the EBCRA, which is represented by the same cultivars in the three locations.
The results of the present work corroborate the idea that the southern Brazilian $P$. coronata $\mathrm{f}$. sp. avenae populations have a high variability for virulence. The inclusion of one subset of $P C$ genes in the NASN was sufficient to distinguish the local isolates and, therefore, the permanent addition of this subset is recommended to improve the efficiency of this system. Furthermore, we have shown that the isolates analyzed in this study have a high level of virulence and did not show a local grouping tendency, indicating that they are distributed uniformly among the three locations of sampling. Moreover, the present studies demonstrate that some few genes still maintain low virulence frequencies and that the great diversity and high levels of virulence among isolates of $P$. coronata f. sp. avenae in Brazil will make it unlikely that long-lasting control of crown rust can be obtained with race-specific resistance.

\section{ACKNOWLEDGMENTS}

We thank FAPERGS, CNPq, and CAPES for the grants and fellowships received; and the Brazilian National Research Center for Wheat (Embrapa Trigo) in Passo Fundo for facilities provided.

\section{LITERATURE CITED}

1. Barbosa-Neto, J. F., Matiello, R. R., Carvalho, F. I. F., Oliveira, J. M. S., Pegoraro, D. G., Schneider, F., Sordi, M. E. B., and Vacaro, E. 2000. Progresso genético no melhoramento da aveia-branca no sul do Brasil. Pesqui. Agropecu. Bras. 35:1605-1612.

2. Benin, G., Carvalho, F. I. F., Oliveira, A. C., Lorencetti, C., Vieira, E. A., Coimbra, J. L. M., Valério, I. P., Floss, E. L., Bertan, I., and Silva, G. O. 2005. Adaptabilidade e estabilidade em aveia em ambientes estratificados. Ciênc. Rur. 35:295-302.

3. Brown, J. K. M., and Hovmoller, M. S. 2002. Aerial dispersal of pathogens on the global and continental scales and its impact on plant disease. Science 297:537-541.

4. Caeirão, E., Carvalho, F. I. F., Floss, E. L., Sánchez-Chacón, C. D., Lorecetti, C., and Marchioro, V. 2001. Efeito de níveis de severidade e incidência da ferrugem-da-folha e ferrugem-do-colmo no rendimento de linhagens de aveia. Pesqui. Agropecu. Bras. 36:43-52.

5. Carvalho, F. F. I., Barbosa-Neto, J. F., Floss, E., Ferreira, A. W. P. F., Franco, F. A., Federizzi, L. C., and Nodari, R. O. 1987. Potencial genético da aveia, como produtora de grãos, no sul do Brasil. Pesqui. Agropecu. Bras. 22:7182.

6. Chong, J. 2000. Incidence and virulence of Puccinia coronata in Canada from 1996 to 1998. Can. J. Plant Pathol. 22:99-109.

7. Chong, J., and Kolmer, J. A. 1993. Distribution and virulence of Puccinia coronata f. sp. avenae in Canada in 1992. Can. J. Plant Pathol. 16:64-67

8. Chong, J., Leonard, K. J., and Salmeron, J. J. 2000. A North American system of nomenclature for Puccinia coronata f. sp. avenae. Plant Dis. 84:580-585.

9. Cruz, R. P., Federizzi, L. C., and Milach, S. C. K. 1999. Severidade da ferrugem-da-folha e seus efeitos sobre caracteres da panícula de aveia. Pesqui. Agropecu. Bras. 34:543-551.

10. Cruz, R. P., Federizzi, L. C., and Milach, S. C. K. 2001. Genética da resistência à ferrugem- da-folha em aveia. Pesqui. Agropecu. Bras. 36:1127-1132.

11. Doehlert, D. C., McMullen, M. S., and Hammond, J. J. 2001. Genotypic and environmental effects on grain yield and quality of oat grown in North Dakota. Crop Sci. 41:10661072.

12. Harder, D. E., and Haber, S. 1992. Oat diseases and pathologic techniques. Pages 307425 in: Oat Science and Technology. H. G. Marshall and M. E. Sorrells, eds. American Society of Agronomy Inc. and Crop Science Society of America Inc., Madison, WI.

13. Holland, J. B., and Munkvold, G. P. 2001. Genetic relationships of crown rust resistance, grain yield, test weight, and seed weight in oat. Crop Sci. 41:1041-1050.

14. Johnston, M. R., Carsten, L. D., Douglas, L., and Sands, D. C. 2000. Epidemic development and virulence in 1995-1998 of Puccinia coronata, a potential biocontrol agent of wild oats on San Clemente Island. Biol. Control 17:250257.

15. Kolmer, J. A., and Chong, J. 1993. Distribution of virulence in two populations of Puccinia coronata f. sp. avenae in Canada. Can. J. Bot. 71:946-950.

16. Leonard, K. J. 2003. Regional frequencies of virulence in oat crown rust in the United States from 1990 through 2000. Plant Dis. 87:13011310.

17. Leonard, K. J., Anikster, Y., and Manisterski, J. 2004. Patterns of virulence in natural populations of Puccinia coronata on wild oat in Israe and in agricultural populations on cultivated oat in the United States. Phytopathology 94:505-514.

18. Leonard, K. J., and Martinelli, J. A. 2005. Virulence of oat crown rust in Brasil and Uruguay. Plant Dis. 89:802-808

19. Lorencetti, C., Carvalho, F. I. F., Marchioro, V. S., Benin, G., Oliveira, A. C., and Floss, E. L. 2004. Implicações da aplicação de fungicida nos parâmetros de adaptabilidade e estabilidade de rendimento de grãos em aveia branca. Ciênc. Rur. 34:693-700.

20. Martinelli, J. A., Chaves, M. S., Federizzi, L. C., Milach, S. C. K., and Almeida, J. L. 1998 Análise da virulência de alguns isolados de Puccinia coronata avenae no Sul do Brasil. In: Reunião da comissão brasileira de pesquisa de aveia. Instituto Agronômico do Paraná, Londrina, Brazil.

21. Martinelli, J. A., Federizzi, L. C., and Bennedeti, A. C. 1994. Redução do rendimento de grãos de aveia em função da severidade da ferrugem da folha. Sum. Phytopathol. 20:116118.

22. Murphy, H. C. 1935. Physiologic specialization in Puccinia coronata avenae. U. S. Dep. Agric. Tech. Bull. 433.

23. Rohlf, F. J. 2000. NTSYS-pc: Numerical Taxonomy and Multivariate Analysis System, Version 2.1. Exeter Software, New York.

24. Sneath, P. H. A., and Sokal, R. R. 1973. Numeric Taxonomy: The Principles and Practice of Numerical Classification. W. H. Freeman, San Francisco.

25. Sokal, R. R., and Michener, C. D. 1958. A statistical method for evaluating systematic relationships. Univ. Kansas Sci. Bull. 38:14091438.

26. Sokal, R. R., and Rohlf, F. J. 1962. The comparison of dendrograms by objective methods. Taxon 11:30-40.

27. van Niekerk, B. D., Pretorius, Z. A., and Boshoff, W. H. P. 2001. Pathogenic variability of Puccinia coronata f. sp. avenae and $P$. graminis f. sp. avenae on oat in South Africa. Plant Dis. 85:1085-1090. 